Książka Unia Europejska po Traktacie ustanawiajacym Konstytucje dla Europy jest wielowątkową publikacją odwołującą się do obecnego stanu integracji europejskiej, funkcjonowania państw narodowych w powiązaniu z Unią Europejską oraz stosunków zewnętrznych Unii, godną polecenia każdemu zajmującemu się problematyką Unii Europejskiej.

ADAM JASKULSKI

\title{
Irma Slomczyńska, Europejska Polityka Bezpieczeństwa i Obrony. Uwarunkowania, struktury, funkcjonowanie, Wydawnictwo Uni- wersytetu Marii Curie-Skłodowskiej, Lublin 2007, ss. 408.
}

Pierwotnym obszarem, w którym dokonywała się integracja europejska była sfera gospodarcza. Pomimo, że już w latach 50-tych XX wieku podejmowano próby zacieśniania współpracy w zakresie polityki zagranicznej i bezpieczeństwa, z powodów oporów przede wszystkim Francji, początki współpracy politycznej państw członkowskich Wspólnot Europejskich datuje się na lata siedemdziesiąte XX w. Przełomem w tej współpracy był Traktat z Maastricht, który wprowadzał postanowienia o Wspólnej Polityce Zagranicznej i Bezpieczeństwa (WPZiB), tzw. „II filar”'Unii Europejskiej. Jednakże postanowienia o WPZiB, które weszły w życie w 1993 r. bardzo szybko zostały negatywnie zweryfikowane przez nieporozumienia i brak współpracy pomiędzy państwami członkowskimi UE.

Podjęte próby zmiany nieefektywnych zapisów Traktatowych związane były m.in. z zabiegami mającymi na celu stworzenie struktur militarnych i wyposażenia Unii w zdolności bojowe w celu prowadzenia operacji wojskowych. Początkowo starano się zgodnie $\mathrm{z}$ koncepcją przyjętą $\mathrm{w}$ roku 1993 powiązać UE z reaktywowaną Unią Zachodnioeuropejską. W późniejszym okresie zrezygnowano jednak z tych zamiarów i po porozumieniu brytyjsko-francuskim doszło do powołania w ramach WPZiB na podstawie art. 17 TUE Europejskiej Polityki Bezpieczeństwa i Obrony (EPBiO).

Książka Irmy Słomczyńskiej Europejska Polityka Bezpieczeństwa i Obrony. Uwarunkowania, struktury, funkcjonowanie podejmuje właśnie problematykę zagadnienia, jakim jest tworzenie polityki bezpieczeństwa i obrony, która zgodnie z zapisami Traktatu o Unii Europejskiej, może w przyszłości prowadzić do wspólnej obrony.

Omawiana książka podzielona jest na trzy części, z których każda składa się z trzech rozdziałów podzielonych na podrozdziały. Oczywiście całość dopełnia wprowadzenie i podsumowanie oraz bibliografia, spis rysunków i tabel.

Część pierwsza poświęcona jest uwarunkowaniom EPBiO. Autorka w trzech rozdziałach prezentuje uwarunkowania: podsystemowe, środowiskowe oraz systemowe. Te pierwsze zdefiniowane są jako interesy w zakresie bezpieczeństwa wyrażane przez poszczególne państwa członkowskie, właśnie z racji faktu wypływania ich ,z wnętrza państw członkowskich”, otrzymują miano podsystemowych. Interesy te składają się natomiast z elementów sprzecznych, komplementarnych oraz identycznych. Są to m.in.: przetrwanie i bezpieczeństwo państwa, jego suwerenność czy rozwój i jego tożsamość - w zakresie elementów identycznych. W przypadku sprzecznych interesów są to, np. interesy: zależne od położenia geopolitycznego, uzasadniane doświadczeniem historycznym czy pojmowaniem własnego bezpieczeństwa. Natomiast w zakresie interesów komplementarnych można m.in.: wyróżnić: przeciwdziałanie wyzwaniom i zagrożeniom bezpieczeństwa czy promowanie wspólnych wartości i celów (pokój, bezpieczeństwo, stabilność). Jako główne osie podziału wśród państw członkowskich można wskazać podział na: państwa o aspiracjach do odgrywania roli globalnej i pozostałe, państwa neutralne i prowadzace politykę zaangażowania w sojusze militarne oraz państwa powiązane blisko ze Stanami Zjednoczonymi Ameryki i optujące za współpracą z tym państwem oraz państwa będące przeciw bliskiej współpracy ze Stanami Zjednoczonymi Ameryki. 
Rozdział drugi analizuje uwarunkowania środowiskowe, $\mathrm{tj}$. uwarunkowanie wypływające z otoczenia systemu. Trzy główne punkty dotyczą: współpracy między Stanami Zjednoczonymi Ameryki a Unią Europejską, skutków uczestnictwa państw członkowskich UE w organizacjach międzynarodowych (NATO, OBWE, Rada Europy czy ONZ) oraz charakteru podmiotowości Unii Europejskiej i jej wpływu na pozycję międzynarodową UE.

Trzeci rozdział (uwarunkowania systemowe) wskazuje przede wszystkim na podstawy prawne funkcjonowania EPBiO oraz decyzje państw członkowskich związane z tą strukturą, chociażby próby reform $\mathrm{EPBiO}$ oraz decyzję podejmowane przez państwa członkowskie poza forum Unii Europejskiej w formule dwustronnej lub wielostronnej. Podstawowe znacznie miały $\mathrm{w}$ tym aspekcie decyzje związane $\mathrm{z}$ porozumieniem brytyjsko-francuskim dotyczacym powołania do życia EPBiO i jej założeń.

W drugiej części książki Autorka dokładnie przedstawia struktury EPBiO. Instytucje zostały podzielone na trzy grupy (struktury formułowania strategii politycznej, struktury opracowywania taktyki działania i struktury formowania operacji), każda grupa zaprezentowana w innym rozdziale. W ramach tej części opisano: Radę Europejską, Radę ds. Ogólnych i Stosunków Zewnętrznych, COREPER, Parlament Europejski, Instytut Studiów Bezpieczeństwa Unii Europejskiej, Europejskie Kolegium Bezpieczeństwa i Obrony, Europejską Agencję Obrony, Centrum Satelitarne (grupa pierwsza), Sekretarza Generalnego Rady/Wysokiego Przedstawiciela ds. WPZiB, Sekretariat Generalny Rady, Komitet Polityczny i Bezpieczeństwa, Komitet Wojskowy Unii Europejskiej, Sztab Wojskowy Unii Europejskiej, Komitet ds. Cywilnych Aspektów Zarządzania Kryzysami, Komisję Europejską (grupa druga), Komórki Planistyczne, Komitet Współuczestników, Mechanizm Finansowania Operacji (grupa trzecia). Na szczególną uwage zasługują wszelkie instytucje „wyspecjalizowane”, tj. stworzone dla funkcjonowania EPBiO, gdyż w tym przypadku bardzo dynamiczny rozwój nowych struktur wskazuje na próbę wzmacniania tych specyficznych polityk bezpieczeństwa i obrony poprzez instytucjonalizację działań UE.

Trzecia część książki dotyczy prezentacji praktycznej realizacji zadań w ramach EPBiO. Po pierwsze (rozdział siódmy), analizie zostaje poddana Europejska Strategia Bezpieczeństwa z 2003 r., która jest podstawowym dokumentem określającym zagrożenia i wyzwania stojące przed Unią Europejską oraz definiującym środki i metody działania, jakie UE ma wykorzystywać w rozwiązywaniu problemów z zakresu bezpieczeństwa. Po drugie (rozdział ósmy), w tej części przedstawiony zostaje przebieg, z jednej strony projektowania rozwoju zasobów cywilnych i wojskowych (tzw. cele operacyjne), a z drugiej strony ich faktyczna realizacja. Po trzecie (rozdział dziewiąty), przedstawione zostają z wielką dokładnością operacje cywilne i militarne prowadzone przez UE w ramach zarządzania kryzysami.

Zgodnie z oceną Autorki, Europejska Polityka Bezpieczeństwa i Obrony jest obecnie na etapie rozwoju, który pozwala tylko i wyłącznie na prowadzenie operacji zarządzania kryzysami, natomiast nie jest możliwe, pomimo deklaracji decydentów UE i niektórych państw członkowskich, prowadzenie działań militarnych w konfliktach o wysokiej intensywności. Operacje prowadzone w ramach $\mathrm{EPBiO}$, zdaniem Autorki, tak jak było to do tej pory, będą prowadzone w obszarach zagrażających stabilności UE (np. Bliski Wschód) oraz w obszarach, które w perspektywie średnio- i długookresowej mogą stać się członkami UE (np. Bośnia i Hercegowina). W kwestii przyszłej ewolucji i rozwoju $\mathrm{EPBiO}$, według I. Słomczyńskiej, nie nastąpi w najbliższym czasie żaden przełom. W dalszym ciagu pozostanie ona przede wszystkim instrumentem zarządzania kryzysami. Największy wpływ, w ocenie Autorki, zważywszy na międzyrządowy charakter EPBiO, na jej funkcjonowanie, podobnie jak do tej pory będą miały trzy państwa: Francja, Wielka Brytania i Niemcy.

Książka autorstwa Irmy Słomczyńskiej jest pierwszą w polskiej literaturze, która w tak szeroki i kompleksowy sposób obejmuje stosunkowo młodą formę współpracy państw członkowskich, jaką jest Europejska Polityka Bezpieczeństwa i Obrony. Wydawnictwo to wybija się bardzo mocno na tle wcześniejszych opracowań, które ograniczały się do przedstawienia historii EPBiO, podstaw prawnych i wymienienia operacji prowadzonych w jej ramach. Autorka, oprócz tematyki 
dostępnej polskiemu czytelnikowi we wcześniejszych publikacjach innych autorów, analizuje uwarunkowania, które mają podstawowy wpływ na kształt i funkcjonowanie EBPiO, nie ograniczają się one tylko do najważniejszych państw Unii Europejskiej, ale prezentują także interesy mniej znaczących członków UE. Do tego w trzeciej części dochodzi szczegółowa prezentacja Europejskiej Strategii Bezpieczeństwa oraz budowy zdolności operacyjnych UE w zakresie zarządzania kryzysami. Całość dopełnia bardzo dokładny opis prowadzonych misji cywilnych i wojskowych. Warto zwrócić uwagę także na wykorzystywane pozycje bibliograficzne, które stanowią w większości wypadków publikacje zagraniczne, co spowodowane jest m.in. niskim zainteresowaniem tym tematem w naszym kraju oraz wykorzystywanie szerokiego spektrum dokumentów dotyczących $\mathrm{EPBiO}$, a także polityk bezpieczeństwa i obrony prowadzonych przez poszczególne państwa członkowskie. Dlatego też bibliografia może stanowić ważną wskazówkę dla poszukujących bardziej szczegółowych informacji dotyczących tematyki zawartej w książce. Zasadniczo jedynym mankamentem, który można zarzucić tej książce, z którego zresztą Autorka na wstępie się tłumaczy, jest nieuwzględnienie roli państw, które stały się członkami UE po 2004 r., w kształtowaniu Europejskiej Polityki Bezpieczeństwa i Obrony. Przez ten fakt traci się z pola widzenia możliwą ewolucję EPBiO pod wpływem interesów dwunastu nowych państw członkowskich.

Książkę autorstwa Irmy Słomczyńskiej, można polecić wszystkim zainteresowanym rozwojem i funkcjonowaniem polityki zagranicznej i bezpieczeństwa Unii Europejskiej, a w szczególności tym, dla których aspekt militarny współpracy państw członkowskich UE jest najbardziej interesujący.

ADAM JASKULSKI

\section{Zbigniew Czachór (red.), 50 lat i co dalej? Europa i Unia Euro- pejska między integracjq a atomizacjq..., WN INPiD UAM, Poznań 2007, ss. 337.}

Instytut Nauk Politycznych i Dziennikarstwa poznańskiego UAM od wielu lat zajmuje się analizą teorii integracji europejskiej, czego zwieńczeniem jest powstanie w 2004 roku Pracowni Badań nad Integracją Europejską. Publikacja 50 lat i co dalej? Europa i Unia Europejska między integracja a atomizacja... jest efektem dwóch wydarzeń naukowych, których organizatorem obok wspomnianej Pracowni był również Ośrodek Badań i Edukacji Europejskiej. Kompilacja materiałów pochodzących z konwersatorium badawczego pt. „Integracja versus atomizacja. W poszukiwaniu nowych teorii oraz konstrukcji analitycznych wyjaśniających dynamikę zmian w systemie Europy i Unii Europejskiej”, które miało miejsce w listopadzie 2006 r. oraz referatów z konferencji naukowej poświęconej 50 rocznicy podpisania Traktatów Rzymskich, dała asumpt do powstania powyższej pracy pod redakcją naukową prof. Zbigniewa Czachóra.

Na treść publikacji składają się dwadzieścia dwa artykuły naukowe traktujące często w dość szeroki sposób kwestię integracji europejskiej, jak i samą Unię Europejską (UE). Teksty zawarte w książce podzielono na cztery zasadnicze grupy. Intencją owej recenzji nie jest streszczanie całości, w związku z czym spośród wspomnianych grup omówione zostaną najciekawsze rozprawy.

W pierwszej z grup poruszającej kwestię $\mathrm{m}$.in. teorii integracji, został umieszczony tekst poznańskiego wykładowcy. Prof. Andrzej Gałganek w swym artykule zatytułowanym Neośredniowieczna analogia jako proces atomigracji wprowadził pojęcie, które jest połączeniem terminów atomizacji i integracji. Atomigracja jest procesem, którego źródeł na poziomie lokalnym, jak i ponadpaństwowym (systemowym) Autor dopatruje się w neośredniowiecznej koncepcji, zestawiając ją z teorią fragmentacji i konsolidacji Stuart J. Kaufmana. Uważa, iż analogia neośredniowieczna jest użyteczną przy opisie i rozumieniu współczesnych stosunków międzynarodowych, czyli postępującej atomizacji przez samookreślanie składowych systemu oraz wprowadzenia reżimu 